\title{
Measures to prevent emissions of pollutants when burning coals in small-capacity boilers in the central ecological area of the Baikal natural territory
}

Elena Maysyuk ${ }^{*}$, Melentiev Energy Systems Institute of Siberian Branch of the Russian Academy of Sciences, Irkutsk, Russia

\begin{abstract}
The paper presents a brief description of the municipal coalfired boiler plants of the central ecological zone and estimation of the emission of pollutants into the atmosphere. The intensity and volume of emissions depend on many factors. These are the capacity and efficiency of the boiler units, the amount of fuel consumed and its physicochemical properties, the type of furnace and the degree of flue gas cleaning. The study indicates that $25 \%$ of the total emissions from coal-fired boilers is produced by the energy sources with manually - loaded boilers with a unit capacity of up to $1 \mathrm{Gcal} / \mathrm{hr}$ without flue gas cleaning systems. The paper presents the main ways to reduce the emission of harmful substances into the atmosphere from heat production. The best available technologies for reducing emissions into the atmosphere and reducing waste generation are reviewed with a focus on preliminary fuel preparation and cleaning, technological measures and the installation of flue gas cleaning systems. Recommendations on their application in coal-fired small-capacity boiler plants in the central ecological zone of the Baikal natural territory are given. Keywords: small-capacity heat sources, emissions to the atmosphere, best available technologies, fuel preparation for combustion, flue gas cleaning.
\end{abstract}

\section{The research objective}

The Baikal Natural Territory was identified in accordance with the law "On Protection of Lake Baikal" [1]. It includes three ecological zones: the central ecological zone, the zone of atmospheric influence, and the buffer zone. The central ecological zone has a special status of environmental management, which is regulated by the Resolution of the Government of the Russian Federation No. 643 [2] that bans certain types of economic activity, including the construction of new coal-fired boiler plants but allows major overhaul and reconstruction of existing boiler plants.

Corresponding author: maysyuk@isem.irk.ru 
In the central ecological zone, there are 98 municipal heat sources of various capacities, including 66 coal-fired boiler plants, 19 electric boiler plants, 9 wood-, 3 gas-, and 1 fuel oil- fired plants. Coal-fired boilers account for $90 \%$ of the total installed capacity of the heat sources.

Small-capacity boiler plants represent manually-loaded energy sources with the boilers of a unit capacity of up to $1 \mathrm{Gcal} / \mathrm{hr}$ without flue gas cleaning systems. Such boiler plants account for $62 \%$ (or 41 boilers) of the total number of heat sources in the considered territory (Table 1).

Table 1. Characteristic of coal-fired boiler plants in the central ecological zone

\begin{tabular}{|c|c|c|c|c|c|}
\hline \multirow{3}{*}{ Index } & \multicolumn{5}{|c|}{ Unit capacity of boilers, Gcal $/ \mathrm{hr}$} \\
\hline & \multirow{2}{*}{\multicolumn{2}{|c|}{$\begin{array}{c}\text { Manually-loaded } \\
\text { Below } 1\end{array}$}} & \multicolumn{3}{|c|}{ With powered furnace } \\
\hline & & & \multicolumn{2}{|c|}{$1-10$} & Above 10 \\
\hline The number of boiler plants, pcs & & & 16 & 7 & 2 \\
\hline Cleaning equipment & \multicolumn{3}{|c|}{ No } & \multicolumn{2}{|c|}{ Multi-cyclones } \\
\hline Emissions, thousand $\mathrm{t} / \mathrm{yr}$ & 2.6 & 3.4 & 8.0 & 2.8 & 7.1 \\
\hline
\end{tabular}

The largest amount of harmful substances polluting the atmosphere is produced during coal combustion. In general, the amount of pollutant emissions into the atmosphere from energy sources of the central ecological zone is estimated at 23.8 thousand tons/year. The emissions from the small-capacity boiler plants make up 6 thousand tons/yr (or $25 \%$ of the total emission) with the predominant emission (up to 80\%) of particulate matter. In this regard, the main measures to reduce or prevent emissions into the atmosphere during coal combustion should be the measures to eliminate the emissions of the particulate matter as the main pollutant. The particulate matter emission consists of ash particles and carbon in fly ash (particles of unburnt fuel) formed in the boiler furnaces and carried away with flue gases. This emission depends on the amount of fuel burnt, its ash content and the degree of ash collection.

\section{Ways to reduce emissions into the atmosphere}

The main avenues for reducing the emissions of harmful substances into the atmosphere that are currently available in the energy sector are:

- preliminary fuel preparation and cleaning before its combustion with a view to improving the quality of the original fuel;

- technological measures to prevent the formation of harmful impurities in the process of fuel combustion associated with changes in the design of combustion devices, control of combustion conditions, and the use of additives and supplements in the fuel path to suppress the formation of pollutants;

- flue gas cleaning from harmful impurities by catching devices, which involves the installation of special cleaning systems after fuel combustion;

- replacement of one fuel type with a more environmentally friendly one;

- adoption of waste-free technologies, that is, the involvement of products polluting the environment in the same or a new technological process or production.

The choice of measures to reduce emissions of pollutants into the atmosphere is currently determined by the Information and Technical Reference Book (22-2016) [3]. It presents the approaches, measures and methods defined as the best available technology (BAT) for reducing the emissions of harmful substances into the atmosphere in accordance 
with the Federal Law "On Environmental Protection" of January 10, 2002 (clause 28.1, p. 6) and "Guidelines on the Definition of the Best Available Technology" approved by the Order of the Ministry of Industry and Trade of the Russian Federation of March 31, 2015, No. 665 . The best available technologies are only the technologies that are widely used by Russian and foreign entities with industrial implementation, and have the least impact on the atmosphere, given cost-effectiveness, operational efficiency, and the implementation period (short term - from weeks to months, medium term - up to one year, and long term more than a year).

It is worth noting, that the use of BAT at operating facilities is associated with the improvement in cleaning systems, which entails first of all the automation of production processes of emission cleaning, the adoption of energy-saving principles of operation and upgrading of the production processes, the organization of a system for monitoring energy consumption and automatic control of emission mass, the use of reliable and hermeticallysealed equipment to prevent fugitive emissions, and the advanced training of maintenance staff [3].

\section{Available measures to reduce emissions from small-capacity boiler plants}

All the above ways to reduce emissions can be quite applicable to small-capacity boilers. However, the experience of research in the field of small-capacity heating systems shows that in actuality some technologies are not adopted because they require significant investment. For small-capacity boiler plants located in the central ecological zone, such measures as replacement of one type of fuel with another (more environmentally friendly), as well as the implementation of waste-free technologies are not considered.

The pre-treatment and cleaning of fuels prior to combustion can significantly reduce the emission of particulate matter. Fuel cleaning before it is burnt involves coal preparation, i.e. washing coal directly at plants, and gasification of solid fuels at special facilities. Such technologies allow reducing the fuels moisture content, ash content, and sulfur content, and increase their calorific value. The technologies for fuel cleaning before burning with the production of secondary products found their use in the coal mining, oil refining, and byproduct coking industry. In the case of small boiler plants, the improvement in fuel quality through the production of refined coal-based fuels is becoming most relevant. In essence, this is the process of semi-coking or thermal preparation of coal. It is worth noting that such a fuel should be prepared outside the ecological zones, at large CHP or large sorting stations equipped with advanced gas cleaning systems.

The fuel preparation before burning should also include storage, loading/unloading, protection from wind erosion and excessive moisture, as well as energy and resource saving measures, given the application conditions. Such an approach is most acceptable for smallcapacity boilers. Normally, such activities reduce up to $20 \%$ of fuel consumption in boiler plants, and, accordingly, the amount of emission to the atmosphere.

For efficient combustion in fixed-bed boilers, the coal particle size should be 15-30 $\mathrm{mm}$. In practice, boilers are supplied with ordinary fuel with a high content of fines and a maximum size of lumps of $300 \mathrm{~mm}$. Sorting the fuel can increase fuel efficiency by $5-12 \%$. At the same time, the reduction in fuel consumption can be up to $24 \%$, which will entail a corresponding reduction in emissions and in the ash and slag waste formation.

Technological measures to prevent the formation of solid impurities in the process of fuel combustion can help lower the emissions of particulate matter from boilers. These measures should include design and operation activities that improve fuel burnout and 
reduce heat losses of boiler plants through a decrease in air suction, additional boiler lining, etc. The design measures (construction and adoption of special furnaces and burners) are considered to be more reliable because they are comparatively constant in time. The operation measures associated with changes in and regulation of the combustion process can vary in effectiveness and be unstable in time.

One of the effective methods appropriate for boilers is the organization of fuel combustion in a fluidized bed. The fluidized bed is created using hot air and granular material (calcite, dolomite) supplied to the boiler at a considerable rate. Fuel burns out with a highly intensive heat transfer process and an increase in the residence time of the fuel in the combustion zone [4], which contributes to the reduction in the emissions of solid particles of carbon in fly ash to $90-95 \%$, and ash to $40 \%$ [5]. Of particular note are the Kansk-Achinsk coals, which are widely used in the eastern regions of Russia. These coals have the highest $\mathrm{CaO}$ content, which makes it possible to bind (involve) up to $50 \%$ of sulfur in the combustion process, and reduce sulfur oxide emissions up to $80-90 \%$ in case of adding potassium- or sodium-based sorbent or limestone. Moreover, due to a decrease in the temperature of the combustion process in a fluidized bed, the emission of nitrogen oxides decreases by $30-50 \%[5,6]$.

Operation measures allow reducing the formation of NOx, for example, through flue gas recirculation (with a recirculation degree of $8-16 \%$ ), which reduces the combustion temperature by lowering the oxygen concentration. The most effective recirculation is the external recirculation of cooled gases when flue gases are supplied to the blast air, with a recirculation degree of up to $20 \%$ and high loads of the boiler, as well as during gas combustion, since the emission of thermal (air) nitrogen oxides is reduced [7, 8]. The emission of nitrogen oxides can be reduced to $90 \%$ by injecting ammonia and blowing the flue gases through a catalyst.

Switch to automated boilers should also be attributed to technological measures, which not only improves the quality of operation but also fundamentally changes the nature of boiler plant operation by automating the equipment, which is absolutely impossible when run-of-mine fuel is used. Automated coal-fired boilers are available in the domestic market ("Thermobot", "Prometheus" boilers). The use of this equipment for small-capacity boiler plants of the central ecological zone is quite possible during their reconstruction. It is important that this technology solve three main problems of boiler plants with fixed-bed fuel combustion. These boilers can initially use high-quality fuel as the design of the boilers meets the regulatory requirements of high efficiency. This, consequently, completely eliminates the factor of human error in maintaining their operating conditions, thus ensuring highly efficient heat production, as well as a significant improvement in environmental parameters. Replacement of manual boilers with an efficiency of $40-50 \%$ will reduce fuel consumption by $40 \%$, and by reducing fuel consumption alone, environmental indicators are improved by the same magnitude.

The available technologies for reducing emissions from small-capacity boiler plants also include special technologies, processes or devices for cleaning and neutralizing flue gases. In this case, such an indicator as the cleaning degree (cleaning efficiency), i.e. the ratio of the mass of the pollutant extracted from gas to the mass of this substance before cleaning is used. The widely used methods for cleaning emissions from particulate matter (dust collection) include the technologies for filtration (various filters), gravity separation (separators, cyclones), and washing (scrubbers) of flue gases. The choice of ash removal devices depends on several factors, and, above all, on the particle size of particulate matter, when the dust is divided into visible particles (with a size of more than $10 \mu \mathrm{m}$ ), microscopic (from 10 to $0.25 \mu \mathrm{m}$ ), and ultramicroscopic (less than $0.25 \mu \mathrm{m}$ ) particles. 
Table 2 presents the data from the reference book on the best available technologies recommended for reducing emissions of particulate matter, given their advantages and disadvantages [3]. The prevailing cleaning equipment at the boiler plants on the territory of the central ecological zone consists mainly of multicyclones, i.e. the mechanical plants for dry ash collection. The principle of their operation is based on the fact that ash particles are deposited on the walls of the cyclone due to centrifugal forces during the flow rotation in the body of the plant, and dry ash falls into the hopper. The cleaning efficiency, depending on the type of cyclone (centrifugal, inertia, louver, settling, rotary) varies from $50 \%$ to $90 \%$.

Table 2. The best available technologies for the reduction of particulate matter emissions

\begin{tabular}{|c|c|c|c|c|}
\hline $\begin{array}{c}\text { Size of } \\
\text { particles. } \\
\text { mcm }\end{array}$ & $\begin{array}{l}\text { Recommended } \\
\text { technology }\end{array}$ & $\begin{array}{l}\text { Cleaning } \\
\text { degree, } \\
\% \\
\end{array}$ & Advantages & Disadvantages \\
\hline $\begin{array}{l}\text { Above } \\
20\end{array}$ & $\begin{array}{l}\text { Gravity settling } \\
\text { chambers (ash } \\
\text { collectors) }\end{array}$ & $80-90$ & $\begin{array}{l}\text { Removal of big particulates, } \\
\text { simplicity and reliability of } \\
\text { design and operation; no } \\
\text { moving parts; low energy } \\
\text { consumption }\end{array}$ & $\begin{array}{l}\text { Large overall dimensions and low } \\
\text { dust collection efficiency }\end{array}$ \\
\hline $5-10$ & $\begin{array}{l}\text { Cyclones } \\
\text { (centrifugal single or } \\
\text { multi-cyclones, } \\
\text { vortex, dynamic and } \\
\text { inertia) }\end{array}$ & $50-80$ & $\begin{array}{l}\text { Removal of abrasive particles; } \\
\text { no rotating parts; reliability; } \\
\text { dry dust, high gas pressure; } \\
\text { simplicity of design }\end{array}$ & $\begin{array}{l}\text { High hydraulic resistance } 1250- \\
1500 \mathrm{~Pa} \text {, poor trapping of particles } \\
\text { less than } 5 \mu \mathrm{m} \text { in size; at high gas } \\
\text { flow rates - a group layout } \\
\text { requires a considerable height and } \\
\text { a common dust collection hopper. } \\
\text { A need for additional blowing } \\
\text { device in vortex cyclones; an } \\
\text { increase in gas volume; more } \\
\text { complex operation }\end{array}$ \\
\hline $\begin{array}{l}\text { More } \\
\text { than } 1\end{array}$ & $\begin{array}{l}\text { Electric filters } \\
\text { (lamellar, tubular, } \\
\text { honeycomb; by the } \\
\text { number of electric } \\
\text { fields-2-field and } \\
\text { multi-field; dry and } \\
\text { wet) }\end{array}$ & 99 & $\begin{array}{l}\text { Removal of large particles; low } \\
\text { energy consumption (usually } \\
0.3-1.8 \mathrm{MJ}(0.1-0.5 \mathrm{kWh}) \text { per } \\
1000 \mathrm{~m} 3 \text { of gas; operate under } \\
\text { pressure in vacuum, in } \\
\text { corrosive environments; full } \\
\text { automation. It is economically } \\
\text { feasible to reconstruct obsolete } \\
\text { filters. }\end{array}$ & $\begin{array}{l}\text { High sensitivity to deviations } \\
\text { from given process parameters } \\
\text { and to minor mechanical defects } \\
\text { in the active zone; } \\
\text { Occurrence of spark discharges, } \\
\text { i.e. a high fire hazard }\end{array}$ \\
\hline $0,5-1$ & $\begin{array}{l}\text { Venturi scrubbers } \\
\text { (dirty gas entering a } \\
\text { scrubber is forced at } \\
\text { high velocity } \\
\text { through a Venturi } \\
\text { where it collides } \\
\text { with scrubbing } \\
\text { water. The tiny } \\
\text { water droplets } \\
\text { capture particles) }\end{array}$ & $96-98$ & $\begin{array}{l}\text { Can be used as absorbers for } \\
\text { cooling and moistening gases, } \\
\text { as mixing heat exchangers, } \\
\text { higher cleaning degree } \\
\text { compared to dry scrubbers }\end{array}$ & $\begin{array}{l}\text { Clogging of gas ducts and } \\
\text { equipment with dust; fluid loss; } \\
\text { the need for corrosion protection }\end{array}$ \\
\hline $\begin{array}{l}\text { Less } \\
\text { than } 1\end{array}$ & $\begin{array}{l}\text { Emulsifiers with } \\
\text { hydraulic ash } \\
\text { removal }\end{array}$ & 99.4 & $\begin{array}{l}\text { High cleaning efficiency due to } \\
\text { a large number of gases and } \\
\text { continuity of processes } \\
\text { Simultaneous capture of sulfur } \\
\text { and nitrogen oxides up to } 92- \\
99 \% \text {. }\end{array}$ & $\begin{array}{l}\text { The need to provide the systems } \\
\text { for the regeneration of spent } \\
\text { absorbents, and the disposal of } \\
\text { sludge leads to higher costs and } \\
\text { complication of operation, fluid } \\
\text { loss }\end{array}$ \\
\hline $\begin{array}{l}\text { Less } \\
\text { than } 0.25\end{array}$ & Bag filters & 99.9 & $\begin{array}{l}\text { Removal of small and ultrafine } \\
\text { particles. Easy to operate, } \\
\text { reliable, effective. }\end{array}$ & $\begin{array}{l}\text { Unsuitable for wet or sticky dust; } \\
\text { large overall dimensions }\end{array}$ \\
\hline
\end{tabular}


At present, modern cleaning equipment, suitable and affordable for boiler plants emitting large abrasive particles can be grouped by power and type of boilers [9]:

- for small-capacity hot-water boilers (of $\mathrm{KVr}$ and $\mathrm{KVm}$ type) up to $1 \mathrm{Gcal} / \mathrm{hr}$ :

- ash collectors,

- multi-cyclone BC-259;

- for boilers of small and medium capacity (up to $10 \mathrm{Gcal} / \mathrm{hr}$ ):

- multi-cyclone BC-2,

- for large boilers with a capacity of more than $10 \mathrm{Gcal} / \mathrm{hr}$ :

- multi-cyclone BC-512.

Three types of ash collectors are recommended for small-capacity boilers. These are ash collector ZU, multi-cyclone BC-259, and multi-cyclone BC-2.

The ash collectors $\mathrm{ZU}$ represent a horizontal cyclone of dry inertia gas cleaning from fly ash (more than $50 \mu \mathrm{m}$ ) with a maximum temperature of $260^{\circ} \mathrm{C}$, particulate matter is accumulated in a special hopper delivered with ash collectors (Figure 1) [9]. The ash collector ZU can be installed either directly behind the boiler in the boiler plant or for a group of boilers - outside the boiler plant.
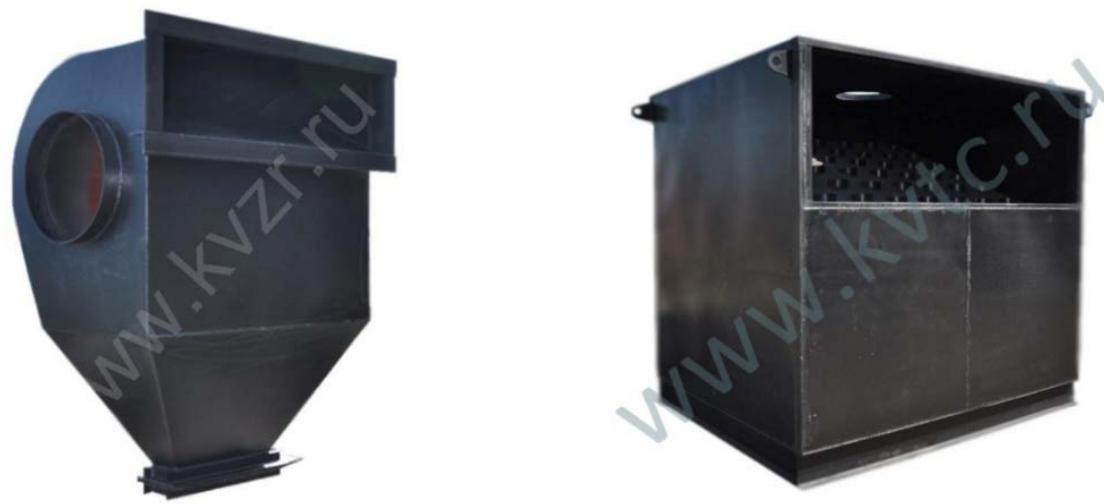

Fig.1. Ash collector ZU 0.8 and ash hopper

The multi-cyclone BC-259 consists of a set of steel cyclone elements with an internal diameter of $259 \mathrm{~mm}$, exhaust pipes with swirl vanes, a grate and a support for casing and the top panel with thermal insulation, a connecting pipe and a hopper for dry ash collection.

The multi-cyclone BC-2 is used in coal-fired steam and hot-water boilers of medium and low capacity. BC-2 is an ash collector made up of parallel cyclone elements that are mounted in one housing and have common inlet and outlet for gas stream, and ash collection hopper. The temperature of the gas to be cleaned is below $400{ }^{\circ} \mathrm{C}$.

As a rule, all multi-cyclones are installed in the gas path behind the boiler before the smoke exhauster. For normal operation of the multi-cyclone, it is necessary to maintain resistance under the minimum load of the boiler, which requires that one of the cyclones be disconnected, the external air leakage be prevented, and overflow of ash hopper be avoided, and to fully remove the collected ash from the hopper when the boiler stops. The appearance of the multi-cyclone is shown in Fig. 2 [9]. 


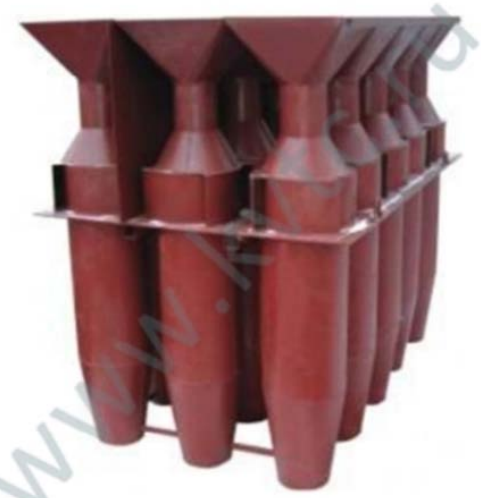

Fig.2. A multi-cyclone

Comparative characteristics of ash collectors and cyclones of various modifications are given in Table 3. It is worth noting that Table 3 presents indicators of some recommended ash collectors but each specific case requires that the equipment to be chosen have appropriate characteristics and cost indicators. The prices for equipment do not include the cost of transportation, assembly, and installation of equipment [9].

Table 3. Comparative characteristics of modern ash collectors

\begin{tabular}{|c|c|c|c|c|c|c|c|c|c|}
\hline \multirow[b]{2}{*}{$\begin{array}{c}\text { Boiler } \\
\text { capacity, } \\
\text { Gcal/hr }\end{array}$} & \multirow[b]{2}{*}{$\begin{array}{l}\text { Recommended } \\
\text { ash collector }\end{array}$} & \multirow[b]{2}{*}{$\begin{array}{c}\text { Cleaning } \\
\text { efficiency, } \\
\%\end{array}$} & \multirow[b]{2}{*}{$\begin{array}{l}\text { Gas } \\
\text { flow } \\
\text { rate, } \\
\mathrm{m}^{3} / \mathrm{hr}\end{array}$} & \multirow{2}{*}{$\begin{array}{c}\text { Number } \\
\text { of } \\
\text { elements }\end{array}$} & \multirow[b]{2}{*}{$\begin{array}{c}\text { Mass, } \\
\mathrm{kg}\end{array}$} & \multicolumn{3}{|c|}{ Overall sizes, $\mathrm{mm}$} & \multirow{2}{*}{$\begin{array}{c}\text { Price } \\
\text { without } \\
\text { VAT, } \\
\text { thousand } \\
\text { rubles }\end{array}$} \\
\hline & & & & & & 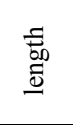 & $\frac{5}{\frac{5}{3}}$ & 泀 & \\
\hline \multirow{2}{*}{ Below 1} & $\begin{array}{l}\text { Ash collector } \\
\text { ZU } 0.8\end{array}$ & 87 & 2400 & - & 153 & 660 & 730 & 1150 & $36.3 *$ \\
\hline & $\begin{array}{l}\text { Multi-cyclone } \\
\text { BC } 259-(3 \times 2)\end{array}$ & 90 & 4.0 & 6 & 1820 & 1580 & 1430 & 3500 & 116.0 \\
\hline Below 10 & $\begin{array}{l}\text { Multi-cyclone } \\
\text { BC-2-6x }(4+2)\end{array}$ & 85 & 29.0 & 36 & 5600 & 2680 & 1890 & 4010 & 595.0 \\
\hline
\end{tabular}

Note: * - price including VAT

Table 4 indicates the minimum and maximum prices in accordance with the rated capacity of ash collectors to estimate the price range of the cleaning equipment.

Table 4. A price range of ash collectors according to their capacity

\begin{tabular}{|l|c|c|c|c|}
\hline \multirow{2}{*}{ Ash collector type } & \multicolumn{2}{|c|}{ Capacity, $\mathrm{m}^{3} / \mathrm{hr}$} & \multicolumn{2}{c|}{$\begin{array}{c}\text { Price (including VAT), } \\
\text { thousand rubles }\end{array}$} \\
\cline { 2 - 5 } & $\min$ & $\max$ & $\min$ & $\max$ \\
\hline Ash collector ZU & 2100 & 8450 & 33 & 66 \\
\hline Multi-cyclone BC-259 & 4 & 32 & 116 & 798 \\
\hline Multi-cyclone BC-2 & 15 & 49 & 332 & 821 \\
\hline
\end{tabular}

As is seen from Table 4, the higher the performance of the cleaning equipment, the higher its price.

Normally, removal of sulfur and nitrogen compounds from flue gases is not provided at boiler plants. This is due to the cumbersome installations that require large space and 
appropriate (explosion-proof, fireproof) infrastructure to place reagents and captured byproducts. Accordingly, the gas cleaning installations will be more expensive than the boiler plant itself.

\section{Conclusions}

All the discussed options are acceptable and affordable for existing small-capacity boiler plants in the central ecological zone. At the same time, the most environmentally compatible of them are multi-cyclones of various modifications with the collection efficiency up to $85-90 \%$. The choice of equipment for cleaning from particulate matter depends on the size of particles and the performance of ash collectors.

Normally, sulfur and nitrogen compounds are not removed from flue gases from boiler plants. For this purpose, preventive measures are used to suppress the formation of gas emissions during coal combustion. The fuel combustion in a fluidized bed makes it possible to reduce the emission of sulfur and nitrogen oxides.

An alternative to reducing the number of harmful impurities, both solid and gaseous, is to replace one type of fuel with another, an environmentally friendly one. For example, the conversion of power facilities from coal to natural gas will help avoid the emissions of ash, soot, and sulfur dioxide. In this case, however, the yield of nitrogen oxides will increase, and greenhouse gases $\left(\mathrm{CO}, \mathrm{CO}_{2}\right)$ will remain. The existing estimates of whether or not the conversion of power facilities to gas [10] is effective show that the conversion of small boiler plants (which are often not equipped with cleaning equipment) to gas is most appropriate. At the same time, the construction of new boiler plants using gas as a fuel is more effective than the conversion of the existing sources to gas.

\section{Acknowledgements}

The research was done under the project of the Integration Program of ISC SB RAS, reg. № AAAA-A17-117041250054-8

\section{References}

1. Federal Law No. 94-FZ of 01.05.1999 on the Protection of Lake Baikal (as amended on 14.07.2008). [On-line]. Available: http: //www.baikalfund. ru/library/law/ index.wbp? doc_id = 03856c6f-5a86-4152-baa6-92407ef26116 (accessed 07.11.2017).

2. Decree of the Government of the Russian Federation No. 643 of August 30, 2001 "On Approval of the List of Activities Prohibited in the Central Ecological Zone of the Baikal Natural Territory" with amendments approved by Decree of the Government of the Russian Federation No. 186 (of March 2, 2015)

3. Purification of emissions of harmful (polluting) substances into the atmospheric air during the production of products (goods), and when performing work and rendering services at large-scale enterprises. Information and technology reference book on the best available technologies (ITRB 22-2016). Federal Agency for Technical Regulation and Metrology: Bureau of BAT. M., 212 p. (2016)

4. B.S. Beloselsky, V.I. Baryshev. Low-grade energy fuels: Features of preparation and combustion. M.: Energoatomizdat, 136 p. (1989)

5. V.R. Kotler. Fluidized-bed furnaces: problems and prospects. Energetik, №6, pp. 1012. (1988) 
6. V.A. Anikeev, S.L. Maslennikov. Technological aspects of environmental safety in the energy sector. Energy and Environmen, Iss. 1. pp. 57-65 (2009)

7. D.M. Khzmalyan. Theory of furnace processes: Manual for universities. M.: Energoatomizdat, 352 p. (1990)

8. I.V. Plachkov at all. Power industry and environmental protection. The functioning of the energy industry in the modern world. Book 5.2012-2013. [On-line]. Available: http://energetika.in.ua/ru/books/book-5/part-3/section-2/2-3 (accessed 03/03/2017)

9. The official site of the plant "Teploexpert". Section "Ash collectors". [On-line]. Available: http://kvtc.ru/ash-collectors-08.html (accessed 07/17/2017)

10. B.G. Saneev, I.Yu. Ivanova, E.P. Maysyuk, A.K. Izhbuldin, T.F. Tuguzova. Conversion of boiler plants in the Central Ecological Zone of the Baikal Natural Territory to gas: prerequisites, effects, barriers. Geography and Natural Resources, №6, pp. 27-31 (2016) 